International Journal of Linguistics, Literature and Culture
Available online at https://sloap.org/journals/index.php/ijllc/
Vol. 6, No. 3, May 2020, pages: 1 -8
ISSN: 2455-8028
http://dx.doi.org/10.21744/ijllc.v0i0.000

\title{
Perception of Elementary School Teachers on Laro Ng Lahi in Quirino, Isabela
}

\author{
Mark-Jhon R. Prestoza ${ }^{\text {a }}$ \\ Chrismarie P. Paludipan ${ }^{b}$ \\ Arvinjay E. Abad ${ }^{c}$
}

\section{Article history:}

Submitted: 09 January 2020

Revised: 19 February 2020

Accepted: 27 March 2020

\section{Keywords:}

classroom;

importance;

laro ng lahi;

millenials;

preservation;

\begin{abstract}
The purpose of this study is to determine the Perception of Selected Elementary School Teachers on Laro ng Lahi in Quirino, Isabela. The participants of this study were ten (10) selected Elementary School Teachers, five (5) from Generation X and five (5) from the Millenials. The researchers utilized qualitative research through face to face interviews. The responses were analyzed through descriptive coding using the thematic analysis. Based on the gathered data's, Laro ng Lahi is still being played by pupils despite their access to advanced technologies and some of these are Tumbang Preso, Sipa, Patintero, Tagu-Taguan, Chinese Garter, Sungka, Luksong Tinik, Luksong Baka, Holen, Tug of War, Agawang Sisiw, Bum-Bum Lata, Agawan ng Panyo, Agawan ng Base, and Siyato. The importance of Laro ng Lahi can be classified according to its benefit in terms of health, culture, social aspiration, and values. Laro ng Lahi can be preserved employing continuous engagement in the respective houses and classroom integration by considering the use of native materials.
\end{abstract}

International journal of linguistics, literature and culture (C) 2020. This is an open access article under the CC BY-NC-ND license (https://creativecommons.org/licenses/by-nc-nd/4.0/).

\section{Corresponding author:}

Prestoza, M.J.R.

Quirino National High School, Division of Isabela, Region 02, Philippines

Email address: markjhonprestoza@gmail.com

\footnotetext{
${ }^{a}$ Quirino National High School, Division of Isabela, Region 02, Philippines

${ }^{\mathrm{b}}$ Quirino National High School, Division of Isabela, Region 02, Philippines

${ }^{\mathrm{c}}$ Quirino National High School, Division of Isabela, Region 02, Philippines
} 


\section{Introduction}

People during the early times spend much of their time doing nothing. Not just nowadays people seem too busy. So they needed a form of amusement, then suddenly these traditional games were invented due to the creativity of Filipinos. Ulanday et al. (2017), UP College of Human Kinetics. Traditional Filipino Games or Indigenous games in the Philippines are games commonly played by children, usually using native materials or instruments. In the Philippines, due to the limited resources of toys for Filipino children, they usually invent games without the need of anything but the players themselves. (Wikipedia) As modernization takes place, these games are rarely played due to the advancement of technology (Bakar et al., 2008; Estole, 2018; Miller \& Kuhaneck, 2008). Most of the children nowadays are spending much of their childhood playtime on internet cafes or handheld gadgets instead of socializing and playing different kinds of Laro ng Lahi that for years is a culture of a typical Filipino child. It seems like they are repelling the culture that we inherited to our ancestors which they should be the one to cherish, foster, and preserve it for the next generation.

Filipino children nowadays are left with a choice, to keep up with the flow of modern times, dwell on virtual games and completely leaving behind the traditional sports, but these children don't have to make this choice, at what is needed in this matter is to find a better, drastic and creative solution to create the balance that is justly needed (Thomas, 2012; Podgursky et al., 2004; Ghanizadeh et al., 2006; Witt, 1986).

Therefore, the researchers conducted a study to seek an answer to the Perception of Selected Elementary School Teachers on Laro ng Lahi in Quirino, Isabela. The result of this study will awaken the awareness of readers on how important knowing these Laro ng Lahi as part of our culture and identity. This study focused to answer the following questions (1) What are the Laro ng Lahi that are still being played by pupils? (2) Why it is important to know these Laro ng Lahi? (3) How can we preserve these Laro ng Lahi?

\section{Materials and Methods}

The researchers used the descriptive research design wherein, the researchers described, examined, and gather data to seek answers on the Perception of Selected Elementary School Teachers in Quirino, Isabela. Descriptive research design is a scientific method that involves observing and describing the behavior of a subject without influencing it in any way (Shuttleworth, 2008).

The researchers conducted a face to face interview with the selected participants to collect information that are beneficial in the study. The researchers prepared questions for the participants to answer, anchored to the research problems of the study (Kovačević \& Opić, 2014; Antos \& Rosen, 1975; Payne \& Fletcher, 1983). The researchers utilized pictures and audio recorders to get the exact and accurate information's from the participants.

The researchers used a purposive sampling procedure in selecting the participants. This involves identifying and selecting individuals that are especially knowledgeable about or experienced with a phenomenon of interest (Cresswell \& Clark, 2011). Participants were the ten (10) selected Elementary School Teachers, five (5) from Generation X and five (5) from the Millennials. These teachers who will serve as participants in this study are based on their experiences and knowledge about these Laro ng Lahi and have been in the profession for more than one year. The data that will be collected from the ten teachers are, nonetheless adequate to have meaningful results.

The researchers had undergone several steps to develop the needed instruments to bring out the most desired result which is as follows: (a) The researchers sought permission from the school head and teachers who will serve as their participants: (b) After permission was granted, the researchers conducted a brief orientation for the teachers to understand the purpose and significance of the study. The researchers also explained carefully and the instructions so that the participants will be able to answer the question well: (c) Finally, the information gathered and collected. The data collected will then retrieve for the interpretation and data analysis (UNESCO, 2013).

The researchers used descriptive coding using the thematic analysis wherein, the researchers will identify, analyze, and interpret patterns of meaning within the qualitative data. Thematic analysis is a useful method for examining the perspective of different research participants, highlighting similarities and differences, and generating unanticipated insights (King, 2004; Hermans et al., 2008; Hu et al., 2003; Brenowitz \& Tuttle, 2003). 


\section{Results and Discussions}

This presents and discusses the findings, the analysis and the interpretation of the data on the Perception of Selected Elementary School Teachers on Laro ng Lahi in Quirino, Isabela.

\subsection{Laro Ng Lahi}

The Elementary School Teachers usually observe these Laro ng Lahi that are still being played by pupils, which are: Tumbang Preso, Sipa, Patintero, Tagu-Taguan, Chinese Garter, Sungka, Luksong Tinik, Luksong Baka, Holen, Tug of War, Agawang Sisiw, Bum-Bum Lata, Agawan ng Panyo, Agawan ng Base, and Siyato. This was testified by:

Key Informant: "Tag of war, Agawang Panyo, Hide and seek (Tagu-Taguan), Sipa, Chinese Garter din, Luksong Tinik, Luksong Kabayo (Luksong Baka) iba yung Luksong Tinik sa Luksong Kabayo eh, Tumbang Preso, Bum-Bum Lata, Jackstone, Holen, Sungka yung naglalagay sila ng bato ganun din."

Filipinos are known for being creative. They are fond of playing games where they usually expend their free time most especially in the rural communities. But due to the scarcity of materials to make toys, Filipino children often end up inventing games that do not require anything but the players themselves. They utilize native materials that are usually found in their respective houses or their neighborhood such as empty cans, slippers, rubber bands and many more. They usually play it during holidays or summertime particularly in vast playgrounds or in streets where cars don't usually pass by.

This is similar to the study of Reyes (2017), these games are cheap and easy to do. They mostly do it on the clear street which cars don't usually pass by, some of these games are Luksong Tinik, Tumbang Preso, Taguan (Hide and Seek), Langit Lupa, Patintero, Piko, Sipa, Palosebo, Pitik Bulag, Chinese Garter, Agawam Base, and Siyato.

\subsection{Importance Of Laro $\mathrm{Ng}$ Lahi}

The Philippines is rich in its culture and tradition. One of the most significant aspects of the country's culture and traditions is the traditional games or Laro ng Lahi. It is very popular among children because these are the games or sports that they usually play. Laro ng Lahi emerges its importance in terms of health, culture, social aspiration, and values of pupils.

a) Health

Through playing these Laro ng Lahi, it will develop the motor skills, body coordination, exercise locomotor, apply skill-related activities, and enhance mental capacity. This was testified by:

Key Informant : "Physically maraming matutulong ito para madevelop yung motor skills, coordination ng mga katawan nila para mai apply yung mga Skill-Related Activities at sa ka health nandun na yung coordination.

Translation:

"Physically this helps a lot with the development of motor skills, coordination of their bodies so that they can apply the Skill-Related Activities and your health to that coordination".

Laro ng Lahi offers a lot of benefits in terms of our health. It enables us to experience a healthier lifestyle because it requires physical movement that can keep us fit. Laro ng Lahi is an escape for a stressful day which relieves pain and a good way in relaxing our mind. This is similar to the study of Prakash (2012), that these kinds of traditional games gives happiness to both minds as well as having good health, it also helps the children maintain good emotional stability, and it keeps them fit and healthy. Besides, traditional games develop their physical abilities as they walk, run, and jump improving their bone and muscle structures which

Prestoza, M.-J. R., Paludipan, C. P., \& Abad, A. E. (2020). Perception of elementary school teachers on Laro Ng Lahi in Quirino, Isabela. International Journal of Linguistics, Literature and Culture, 6(3), 1-8. https://doi.org/10.21744/ijllc.v6n3.876 
aid in the enhancement of their immune system (Estole, 2018; Toner et al., 2007; Brook et al., 2000; Maba \& Mantra, 2017).

b) Culture

Philippines is far different from other countries in the world who has its distinct culture and traditions with a touch of colonizers, and one of these is the Laro ng Lahi. Playing these Laro ng Lahi reflects our culture and instills patriotism. This is a part of Filipino culture as a way of entertaining and expending free time utilizing native materials. This was testified by:

Key Informant 1: "It is because it is our cultural treasure that brings good memories."

Key Informant 2: "It reflects our culture, socialization, it develops camaraderie, and friendship"

As it is observed on the generations nowadays, it seems like these Laro ng Lahi are rarely played due to the advancement of technology. We need to stimulate it because it is our cultural heritage that reflects our culture and instills our patriotism. Also, it is a great way in strengthening families and bridging gaps in the communities. This is similar to the definition of the Magna Kultura (2012), that Larong Pinoy is a cultural treasure cherished by generations of Filipinos. Larong Pinoy is more than a game: it is a vehicle to instill patriotism, pave way for family bonding, and a great way to enliven neighborhood communities.

c) Social Aspiration

Laro ng Lahi is a good way of building and maintaining the socialization skills of children because it enables them to establish a good relationship among their playmates. Playing games that are emotionally, environmentally, and socially appropriate for children can affect their social skills and intelligence. This was testified by:

Key Informant: "Nahuhubog ang socialization skills, yung important doon kasi naaano nila kung pano maging sportsmanship, yung ugali nila, mga ugali nila madedevelop pa lalo hindi lang puro pag-aaral naman ang inaatupag. Dapat maging healthy parin ang katawan, para matalino parin. Hindi ka naman totally na magiging matalino kung puro pag-aaral nalang."

Translation:

"Socialization skills are being developed, which is important because they are relevant when it comes to sportsmanship, their habits, their skills can be further developed and not just concentrated on learning. The body should still be healthy, to be wise. You don't have to be smart if you study hard."

Playing Laro ng Lahi enables us to realize the beauty of our unique culture, as well as in establishing our abilities in socialization skills. Besides creating more friends, we are now actually building a strong foundation for a lasting relationship with our playmates or colleagues. It teaches us how to be independent for a moment, which lets us grow and learn important lessons in life. This is similar to the definition of the Magna Kultura (2012), that play is the way kids grow, learn and live. As children continue to grow, so the skills they learn on the playground. From agility and strength-building to socialization and independence, some of our most important lessons are learned outside the classroom.

d) Values

Playing Laro ng Lahi enables you to establish your self-confidence, positive-attitude, develop sportsmanship, camaraderie, and friendship. This was testified by:

Key Informant: "It reflects our culture, socialization, it develops camaraderie, and friendship"

Key Informant: "The games bring fun and develop friendship, among players and so positive-attitude will establish." 
Laro ng Lahi teaches us lifelong lessons which is vital in our everyday living. It strengthens our personality by building the character that molds us to become a productive, meaningful, and better person. Through participation in these Laro ng Lahi, it enables us to realize the beauty of our rich culture and uphold our values through developing sportsmanship, camaraderie, teamwork, honesty and promoting peace in our country. This is similar to the study of De La Cruz (2019), that the Traditional Filipino Games must be played by children of today for it is seen as the best platform for "promoting peace, harmony, goodwill, and camaraderie" in various Philippine communities.

\subsection{Preservation of Laro $\mathrm{Ng}$ Lahi}

Based on Elementary School Teachers, they are preserving these Laro ng Lahi by teaching and letting the pupils play in their free time, most especially in their P.E class every Friday. It can also be preserved utilizing continuous engagement and utilizing it on respective houses and neighborhoods by considering the use of local materials or native materials. This was testified by:

Key Informant: "I a-apply mo sa ano nila, ituturo mo sa kanila, papasubuking palalaruin kasi sa elementary meron nading mga subjects doon sa mga lessons na yon na nai a-apply na namin yang mga Laro ng Lahi nayan, bale nasa P.E. book na namin."

Translation:

"You apply what they teach, you teach them, they are going to play it because elementary there are some subjects in those lessons that we are already applying for our Race Games, even at P.E. our book."

Key Informant \# 6: "Let the pupils play during Physical Education (P.E.) period. Maybe by teaching them how to play the Filipino games, that's the time. They can also play in their respective houses not only in the school. Another one is to motivate them to play native Filipino Games because these games are safe for them and far from radiation."

Laro ng Lahi can be preserved utilizing classroom integration and during P.E. class. Promoting it and by continuous engagement in our respective houses enables us to influence other children to do so, as a key in building a strong relationship, gaining self-confidence, establish positive-attitude and keeping you healthy and fit.

This is similar to the aim of the K to 12 Basic Education Program and the National Indigenous People's Education (IPED) Policy Framework (DepEd Order No. 62, s. 2011), which stipulates that within the framework of maintaining inclusive and effective learning environments. The DepEd shall nurture among all learners and DepEd teaching and non-teaching personnel, respect for human rights and cultural diversity and that DepEd shall promote greater awareness and appreciation of the indigenous people's cultural heritage and history an integral, yet an often neglected, part of the Philippine nation's cultural heritage and history (Section 15-g).

\section{Conclusion}

Laro ng Lahi is a cultural heritage that passed on from generation to generation. Laro ng Lahi plays a big role in shaping our lives, as it molds our character, values and the totality of us, as human beings. As modernization takes place these games seem rarely being played by children. In contrast, in this generation, they still utilize it as part of their pastime using native materials. With the eagerness of preserving this culture, the Magna Kultura Foundation with the partnership of DepEd promotes greater awareness and appreciation of the indigenous people's cultural heritage and history. The resourcefulness and determination of teachers aiding the preservation of this culture, they are integrating it on their lessons by teaching them how important knowing this culture and teaching them how to play.

\section{Recommendations}

The following points are recommended, based upon the findings and conclusion of the study.

Prestoza, M.-J. R., Paludipan, C. P., \& Abad, A. E. (2020). Perception of elementary school teachers on Laro Ng Lahi in Quirino, Isabela. International Journal of Linguistics, Literature and Culture, 6(3), 1-8. https://doi.org/10.21744/ijllc.v6n3.876 
1) To address an immediate action regarding the preservation of these Laro ng Lahi, the researchers recommend that the National Commission for Culture and the Arts, together with the Magna Kultura Foundation and the Department of Education, should strengthen their programs in disseminating information's through encouraging every learner, community leaders, family members, and other private organizations to attend seminars and symposiums.

2) The researchers recommend that the school should integrate these Laro ng Lahi in partnership with the different school organizations most especially the Supreme Student Government or (SSG) during programs most especially in the conduct of intramurals, foundation and students day in order these Laro ng Lahi remain alive and continue to be strengthened and developed.

3) The researchers recommend every community leaders in partnership with the Sangguniang Kabataan (SK), the Project SMILE "Strengthening and Molding Individuals through Laro ng Lahi Engagement” in bringing closer this culture in the hearts of every Filipino. The word smile signifies Filipino's who are strong enough in facing the challenges and problems that they may encounter in life. Every Filipino should have a smile on their faces as a sign of our rich culture, courage, hope, and determination. Instead of playing westernized sports during fiestas, why not to start making change and revive the culture that is proudly Filipino. As a voice of youth, the Sangguniang Kabataan (SK) must be the one to promote this by conducting Larolympics or Sports Fest which features our Laro ng Lahi. Through the continuous implementation of this program, we can help our culture to remain alive, helps us to educate and discipline our youth, and for the sake of the next generation.

Conflict of interest statement

The author(s) declared that they have no competing interest.

Statement of authorship

The author(s) have a responsibility for the conception and design of the study. The author(s) have approved the final article.

Acknowledgments

We are grateful to two anonymous reviewers for their valuable comments on the earlier version of this paper. 


\section{References}

Aguado (2011). Review of Related Literature. http://team13boom.blogspot.com/2013/01/review-of-relatedliterature.html?m=1

Aguado. D, (2013) The traditional Filipino street Games are alive in the Philippines. Magna Kultura Foundation: A Philippine Arts and Culture Organization. https://dickieaguado.wordpress.com/2013/10/03/the-traditionalfilipino-street-games-are-alive-in-in-the-philippines/

Antos, J. R., \& Rosen, S. (1975). Discrimination in the market for public school teachers. Journal of Econometrics, 3(2), 123-150. https://doi.org/10.1016/0304-4076(75)90042-1

Bakar, A., Tüzün, H., \& Çağiltay, K. (2008). Students'opinions of educational computer game utilization: a social studies course case.

Brenowitz, N., \& Tuttle, C. R. (2003). Development and testing of a nutrition-teaching self-efficacy scale for elementary school teachers. Journal of nutrition education and behavior,35(6), 308-311. https://doi.org/10.1016/S1499-4046(06)60345-X

Brook, U., Watemberg, N., \& Geva, D. (2000). Attitude and knowledge of attention deficit hyperactivity disorder and learning disability among high school teachers. Patient education and Counseling, 40(3), 247-252. https://doi.org/10.1016/S0738-3991(99)00080-4

Cresswell, J. W., \& Plano Clark, V. L. (2011). Designing and conducting mixed method research. 2nd Sage. Thousand Oaks, CA, 201.

de la Cruz, J., Gómez-Herreros, F., Rodríguez-Galán, O., Begley, V., de la Cruz Muñoz-Centeno, M., \& Chávez, S. (2018). Feedback regulation of ribosome assembly. Current genetics, 64(2), 393-404. https://doi.org/10.1007/s00294-017-0764-x

Estole (2018). Laro ng Lahi: Its importance in the inclusion to DepEd programs, Published July 31, 2018.

Ghanizadeh, A., Bahredar, M. J., \& Moeini, S. R. (2006). Knowledge and attitudes towards attention deficit hyperactivity disorder among elementary school teachers. Patient Education and Counseling, 63(1-2), 84-88. https://doi.org/10.1016/j.pec.2005.09.002

Hermans, R., Tondeur, J., Van Braak, J., \& Valcke, M. (2008). The impact of primary school teachers' educational beliefs on the classroom use of computers. Computers \& education, 51(4), 1499-1509. https://doi.org/10.1016/j.compedu.2008.02.001

Hu, P. J. H., Clark, T. H., \& Ma, W. W. (2003). Examining technology acceptance by school teachers: a longitudinal study. Information \& management, 41(2), 227-241. https://doi.org/10.1016/S0378-7206(03)00050-8

King, D. A. (2004). The scientific impact of nations. Nature, 430(6997), 311-316. https://doi.org/10.1038/430311a

Kovačević, T., \& Opić, S. (2014). Contribution of traditional games to the quality of students' relations and frequency of students' socialization in primary education. Croation Journal of Education, 16(1), 95-112.

Maba, W., \& Mantra, I. B. N. (2017). An analysis of assessment models employed by the Indonesian elementary school teachers. International Journal of Social Sciences and Humanities, 1(1), 39-45. https://doi.org/10.29332/ijssh.v1n1.38

Magna Kultura, (2012). The importance of preserving traditional games.

Miller, E., \& Kuhaneck, H. (2008). Children's perceptions of play experiences and play preferences: A qualitative study. American Journal of Occupational Therapy, 62(4), 407-415. https://doi.org/10.5014/ajot.62.4.407

Payne, R., \& Fletcher, B. C. (1983). Job demands, supports, and constraints as predictors of psychological strain among schoolteachers. Journal of Vocational Behavior, 22(2), 136-147. https://doi.org/10.1016/00018791(83)90023-4

Podgursky, M., Monroe, R., \& Watson, D. (2004). The academic quality of public school teachers: An analysis of entry and exit behavior. Economics of Education Review, 23(5), 507-518. https://doi.org/10.1016/j.econedurev.2004.01.005

Prakash, N. (2012). ICT and women empowerment in a rural setting in India. In Globalization, technology diffusion and gender disparity: Social impacts of ICTs (pp. 15-24). IGI Global.

Reyes, J. D. (2017). Re-Thinking Art Education (Revisited), or How I Learned to Love Art Schools Again. Beyond Critique: Contemporary Art in Theory, Practice, and Instruction, 171.

Shuttleworth, M. (2008). Case study research design. Podcast retrieved from http://www. experiment-resources. com/case-studyresearch-design. html, 10(23), 2011.

Shuttleworth, M. (2008). Qualitative research design.

Prestoza, M.-J. R., Paludipan, C. P., \& Abad, A. E. (2020). Perception of elementary school teachers on Laro Ng Lahi in Quirino, Isabela. International Journal of Linguistics, Literature and Culture, 6(3), 1-8. https://doi.org/10.21744/ijllc.v6n3.876 
Thomas, T., Herring, M., Redmond, P., \& Smaldino, S. (2013). Leading change and innovation in teacher preparation: A blueprint for developing TPACK ready teacher candidates. TechTrends, 57(5), 55-63. https://doi.org/10.1007/s11528-013-0692-7

Toner, P., Connolly, M., Laverty, L., McGrath, P., Connolly, D., \& McCluskey, D. R. (2007). Teaching basic life support to school children using medical students and teachers in a 'peer-training'model — results of the 'ABC for life'programme. Resuscitation, 75(1), 169-175. https://doi.org/10.1016/j.resuscitation.2007.03.009

Ulanday, K. T., Jeffery, D. D., Nebeling, L., \& Srinivasan, S. (2017). Perceived deterrence of cigarette use and smoking status among active duty military personnel. Military medicine, 182(5-6), e1733-e1741.

UNESCO, (2013). Review of Related Literature.

Witt, J. C. (1986). Teachers' resistance to the use of school-based interventions. Journal of School Psychology, 24(1), 37-44. https://doi.org/10.1016/0022-4405(86)90040-3 